\title{
UTJECAJ EKOLOŠKIH ČIMBENIKA NA RASPROSTRANJENJE KRANJSKOG LJILJANA (Lilium carniolicum Bernh. ex Koch) U HRVATSKOJ
}

\author{
THE EFFECTS OF ECOLOGICAL FEATURES \\ ON THE DISTRIBUTION OF CARNIOLAN LILY \\ (Lilium carniolicum Bernh. ex Koch) IN CROATIA
}

I. Ljubičić, Marija Horvat, Tamara Brlek

\section{SAŽETAK}

Kranjski ljiljan (Lilium carniolicum Bernh. ex Koch) je trajna zeljasta biljka iz porodice ljiljana (Liliaceae). Raste na livadama i rubovima šuma i planinskih područja istočnih alpa: od Italije do Bosne. Zbog ljepote cvjetova (perigon) u Sloveniji je zakonom zaštićena već od 1947 godine. U Crvenoj knjizi vaskularne flore Republike Hrvatske vodi se u kategoriji osjetljivih (VU) biljaka te je zaštićena vrsta. Zbog velikog potencijala kranjskog ljiljana cilj je bio napraviti model potencijalnog rasprostranjenja s obzirom na ekološke čimbenike na području Hrvatske. Područje istraživanja su gorska i planinska područja Hrvatske, a model je napravljen metodom maksimalne entropije koja se pokazala pouzdanom u usporedbi s drugim metodama ekološkog modeliranja. Podaci o rasprostranjenosti kranjskog ljiljana preuzeti su iz baze podataka Flora Croatica (FCD), dok su klimatske podloge u obliku rasterskih slojeva preuzete iz WorldClim baze podataka koje su usklađene na istu rezoluciju, veličinu i WGS86 (World Geodetic System) koordinatni referentni sustav (CRS). Model je napravljen na temelju 12 klimatskih varijabli koje su prikazane $\mathrm{u}$ rasterskom obliku $\mathrm{s}$ vrijednostima piksela $\mathrm{u}$ rezoluciji $1 \mathrm{x} 1 \mathrm{~km}$. Svakoj točki prisutnosti vrste pridružena je vrijednost piksela svake klimatske varijable. Rezultati pokazuju da varijabla Bio18 (oborine najtoplijeg kvartala) ima statistički značajno najveći utjecaj na pogodnost staništa kranjskog ljiljana s $32,2 \%$.

Ključne riječi: ekološka niša, Hrvatska, Lilium carniolicum, maksimalna entropija 
I. Ljubičić i sur.: Utjecaj ekoloških čimbenika na rasprostranjenje kranjskog ljiljana (Lilium carniolicum Bernh. ex Koch) u Hrvatskoj

\begin{abstract}
Carniolan lily (Lilium carniolicum Bernh. ex Koch) is a perennial herbaceous plant from the Liliaceae family, growing on the meadows and edges of forests and mountainous areas of the eastern alps: from Italy to Bosnia. Because of its beauty habitus and flowers it is often threatened and has been protected in Slovenia since 1947. In the Flora Croatica Red Book it is managed in the category of vunerable (VU) plants. Due to its great potential of Carniolan lily, the aim was to make a model of potential distribution with regard to ecological factors in Croatia. The field research was the mountain regions of Croatia and the model was done by the method of maximum entropy which proved to be reliable compared to other ecological modeling methods. The data of the distribution of Carniolan lily are taken from the Flora Croatica Database (FCD), while climatic layers in the form of raster are used from WorldClim databases, which are aligned to the same resolution, size and WGS86 (World Geodetic System) coordinate reference system (CRS). The model is based on 12 climate variables that are shown in raster form with pixel values at a resolution of $1 \times 1 \mathrm{~km}$. Each pixel point of the species is associated with the pixel value of each climatic variable. The results show that the variable Bio18 (percipitation of warmest quarter) has statistically significant influence on habitat suitability of Carniolan lily with $32.2 \%$.
\end{abstract}

Key words: ecological niche, Croatia, Lilium carniolicum, maximum entropy

\title{
UVOD
}

Kranjski ljiljan (Lilium carniolicum Bernh. ex Koch) je ugrožena vrsta koja prema Flora Croatica Database (FCD) ima status osjetljive svojte (VUvulnerable) (Nikolić, 2020.). U narodu je poznat još i kao kranjski lijer i ciganske minđušice, a pripada rodu Lilium. Latinski naziv roda Lilium potječe od grčke riječi "leirios" što znači nježan, a ime vrste carniolicum ukazuje na slovensku pokrajinu Kranjsku (lat. Carniola). Staništa kranjskog ljiljana su livade i šumski rubovi brdskih i planinskih predjela (Ljubičić i sur., 2010). U Hrvatskoj raste na gorskim i planinskim livadama, na grmljem obraslim obroncima te u šumskim zajednicama razreda Querco-Fagetea Br.-Bl. et Vlieger 1937 (Trinajstić, 2008.) na 380-730 m/nm (Nikolić i Topić, 2005.). Veliki broj jedinki ove vrste pronađen je na području gorske Hrvatske (Mihelj, 1989.). U središnjoj Hrvatskoj pojavljuje se na istoku do Kalnika, a u 
I. Ljubičić i sur.: Utjecaj ekoloških čimbenika na rasprostranjenje kranjskog ljiljana (Lilium carniolicum Bernh. ex Koch) u Hrvatskoj

primorskoj Hrvatskoj vrsta nije zamijećena južno od Splita. Osim na području Hrvatske, kranjski ljiljan rasprostranjena je vrsta i na području sjeverne Italije, Slovenije, Austrije te zapadne Bosne i Hercegovine.

U podzemnom dijelu ovaj ljiljan ima jajoliku lukovicu. Stabljika je visoka 50-100 cm, a na vrhu nosi najčešće samo jedan cvijet (perigonum). Listovi su izmjenično i gusto poredani. Suličasti su, dugi oko $8 \mathrm{~cm}$ i uspravno rastući. Iznad korijenovog vrata su najširi, a na rubu i s donje strane na žilama su papilozno trepetljikavi. Cvjetovi su pravilni, dvospolni i prostolatični. Ugodnog su mirisa, a mogu biti žute do narančaste ili crvenonarančaste boje cvjetova, što ovisi o podrvrsti. Perigon se sastoji od šest listića, koji su do $5 \mathrm{~cm}$ dugi, u luku su svinuti prema dole. Vrsta cvjeta od lipnja do kolovoza. Andrecej ima šest prašnika, a prašničke niti su dugačke i nose velike prašnice žute boje. Plod je tobolac u kojem se nalazi puno sjemenki dugih šest $\mathrm{mm}$. Zbog dekorativnih svojstava (Slika 1.) sadi se u vrtovima, što uzrokuje pretjerano sabiranje i iskapanje jestivih lukovica na prirodnim staništima zbog čega dolazi do smanjenja njegovog areala i staništa (Vitasović Kosić i sur., 2009.).

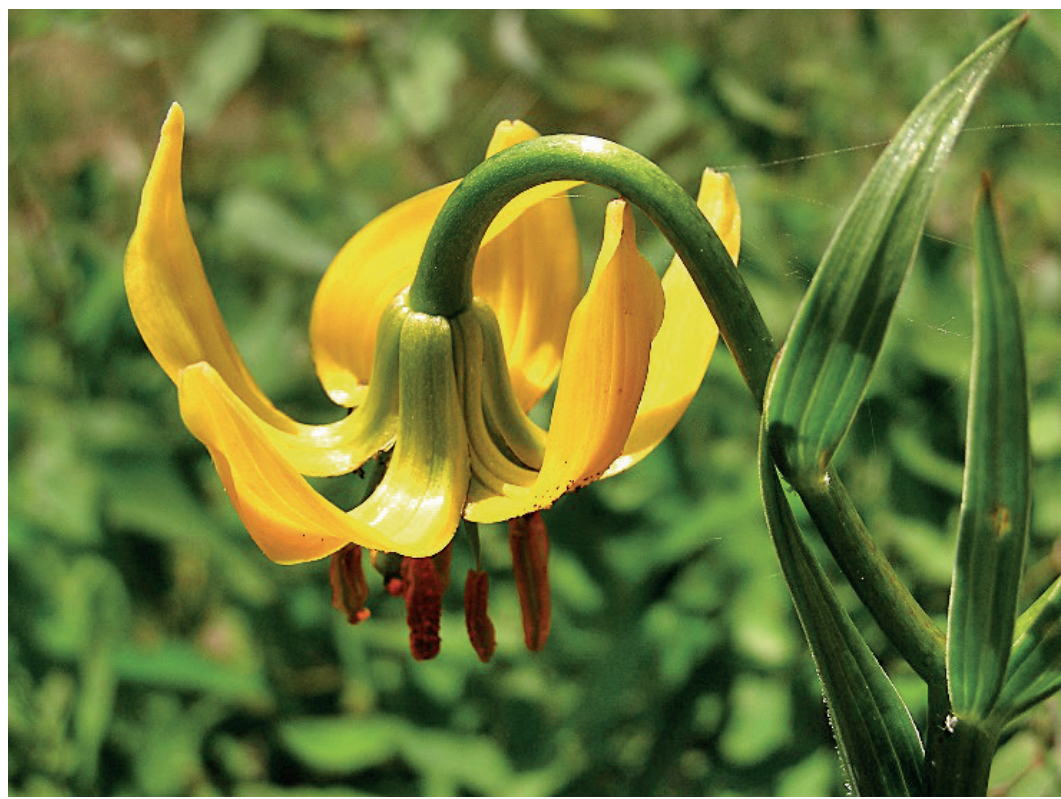

Slika 1. Kranjski ljiljan (Lilium carniolicum) (Izvor: Ivica Ljubičić, 2004.)

Figure 1 Lilium carniolicum (Source: Ivica Ljubičić, 2004.) 
I. Ljubičić i sur.: Utjecaj ekoloških čimbenika na rasprostranjenje kranjskog ljiljana (Lilium carniolicum Bernh. ex Koch) u Hrvatskoj

Posljednjih desetljeća sve je raširenija upotreba snimaka daljinskog promatranja i GIS-a $\mathrm{u}$ analizama prostora $\mathrm{s}$ ciljem što učinkovitijeg gospodarenja resursima. U kombinaciji s prikladnim statističkim metodama, moguće je analizirati velike količine podataka i izraditi prediktivnu kartu (model) rasprostranjenosti. Zbog velikog potencijala Kranjskog ljiljana (Lilium carniolicum Bernh. ex Koch), cilj je bio napraviti model ekološke niše odnosno potencijalnu distribuciju u vidu pogodnosti staništa u GIS sučelju. Korištenjem bioklimatskih varijabli u rasterskom obliku i distribucije poznatih geokoordinata nalazišta, napravljena je karta prediktivnog modela za predviđanje rasprostranjenja kranjskog ljiljana unutar rasterskog GIS okruženja na gorskom i planinskom području Hrvatske. GIS je geografski informacijski sustav koji omogućuje vizualizaciju, upravljanje, uređivanje, analiziranje i publiciranje prostornih informacija. Omogućuje stvaranje novih karata temeljenih na većem broju slojeva (vektorskih ili rasterskih). Karte mogu biti sastavljene u različitim formatima i za različite namjene. Vektorski podaci mogu biti u obliku točaka, linija ili poligona. U programu su podržani različiti oblici rasterskih slika, a također se mogu georeferencirati i slike. Program Quantum GIS (QGIS) podržava različite operacijske sustave uključujući Mac OS X, Linux, BSD i Windows. QGIS je program otvorenog pristupa (Open source) i preveden na 50-ak jezika, a aplikacija se koristi u međunarodnim akademskim i profesionalnim okruženjima.

Maksimalno modeliranje entropije uspješno se primjenjuje na računalnu viziju, prostornu fiziku, obradu prirodnog jezika i mnoga druga područja (Phillips i sur. 2006.). Temeljeći se na Hutchinsonovom konceptu ekološke niše, ova faktorska analiza uspoređuje u višedimenzionalnom prostoru ekološke varijable, te distribuciju lokaliteta u kojima je fokalna vrsta promatrana na referentnom skupu koji opisuje cijelo područje istraživanja (Hirzel i sur., 2002.). Metoda je već korištena $\mathrm{u}$ istraživanju ljekovite kadulje na Balkanskom poluotoku (Rešetnik i sur, 2016.) i lanilista u Španjolskoj (Fernández-Mazuecos i Vargas, 2013.). U istraživanju obične jele, model ekološke niše napravljen je pomoću logističke regresije (LOGREG) (Anić i sur, 2009.). Metoda maksimalne entropije u programu Maxent 3.3. pokazala se pouzdanom u usporedbi s drugim metodama modeliranja (Elith i sur. 2006.). Pregled literature (Pearson i sur., 2007.; Kumar i Stohlgren, 2009.; Vessella i Schirone, 2013.; Oke i Thompson, 2015.; Yi i sur. 2016.) dokazuje visoku pouzdanost metode te je uspješnost metode potvrđena i u ovom istraživanju. 
I. Ljubičić i sur.: Utjecaj ekoloških čimbenika na rasprostranjenje kranjskog ljiljana (Lilium carniolicum Bernh. ex Koch) u Hrvatskoj

\section{MATERIJALI I METODE}

Područje istraživanja su gorska i planinska područja Hrvatske, gdje prevladava umjereno topla vlažna klima s toplim ljetom. Srednje temperature zraka u siječnju kreću se između -2 i $0{ }^{\circ} \mathrm{C}$, a u srpnju od 18 do $22{ }^{\circ} \mathrm{C}$ (Crometeo, 2018.). Ova klimatska područja imaju znatne prostorne razlike u godišnjoj količini padalina te su padaline dosta ravnomjerno raspoređene tijekom godine, s proljetnim i jesenskim maksimumom. Snijeg se najčešće na tlu zadržava do 40 dana godišnje.

Za modeliranje ekološke niše kranjskog ljiljana, preuzeto je 395 GPS točaka s podacima o raspostranjenosti vrste u Republici Hrvatskoj iz baze podataka Flora Croatica (FCD) (Nikolić, 2020.). Podaci GPS koordinata nalaza kranjskog ljiljana prikazani su na Slici 2., a temelje se na literaturnim podacima, herbarijskim primjercima i opažanjima na terenu.

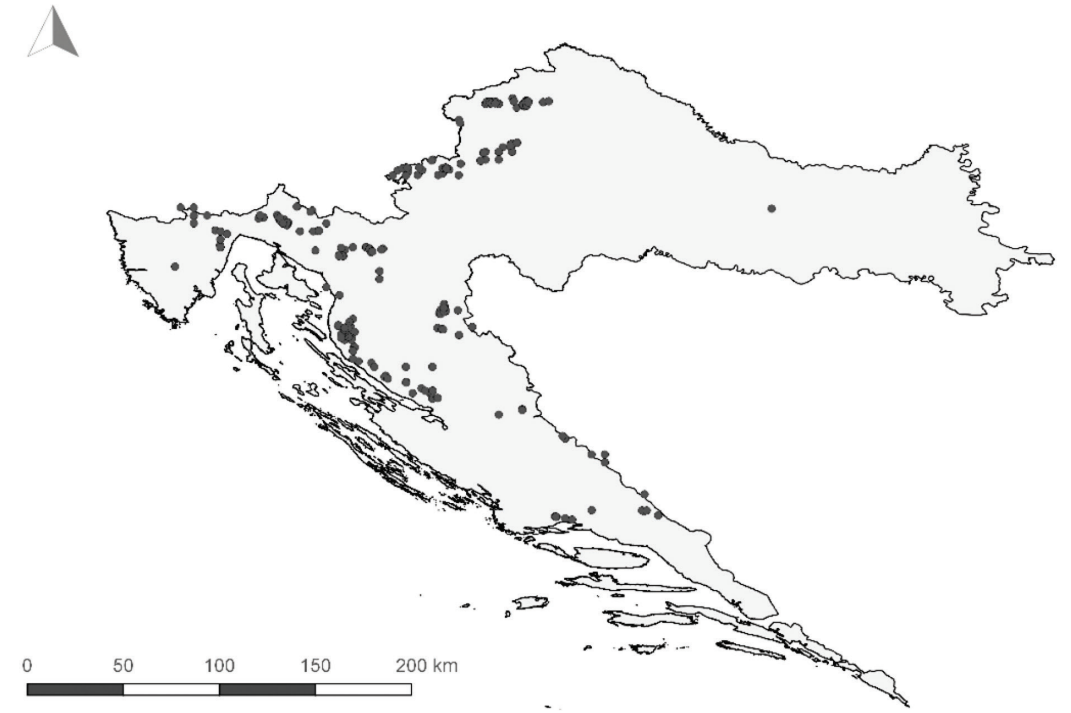

Slika 2. Rasprostranjenost vrste Lilium carniolicum u Hrvatskoj (395 GPS točaka) Figure 2 Distribution of Lilium carniolicum plant species in Croatia (395 GPS points)

Klimatske podloge (slojevi) preuzete su iz WorldClim baze podataka (http://worldclim.org/current) (Fick i Hijmans, 2018.). WorldClim je skup globalnih klimatskih slojeva (gridiranih klimatskih podataka) s prostornom rezolucijom od $1 \mathrm{~km}^{2}$. Ti se podaci mogu koristiti za mapiranje i prostorno modeliranje (Phillips i Dudig, 2008.). Sve preuzete podloge u obliku rasterskih 
I. Ljubičić i sur.: Utjecaj ekoloških čimbenika na rasprostranjenje kranjskog ljiljana (Lilium carniolicum Bernh. ex Koch) u Hrvatskoj

slojeva obrađene su na istu: rezoluciju tj. $1 \mathrm{x} 1 \mathrm{~km}$, veličinu (extent Hrvatska), koordinatni sustav (WGS 84 CRS). Od ukupno 19 dostupnih, korišteno je 12 klimatskih varijabli jer sedam varijabli nema značaj za razvoj vrste ili su u visokoj korelaciji s nekom drugom varijablom (Tablica 1). S obzirom da su podaci klimatskih varijabli za područje cijele Europe, slojevi su izrezani samo za područje Republike Hrvatske i spremljeni u "asc" formatu (Slika 3.). Rasterski slojevi za Hrvatsku su izrezani "kao extent" koji obuhvaća cijeli pixel, a u QGIS programu su svi izrezani odjednom naredbom "Excecute as batch". U zadnjem koraku, svakoj točki prisutnosti vrte pridružena je vrijednost piksela svake klimatske varijable u programu Quantum GIS 3.10. Coruña. Model ekološke niše napravljen je metodom maksimalne entropije u programu Maxent 3.3 (Phillips i sur. 2006.). Takav model projiciran je u geografski prostor i izrađena prediktivna karta.

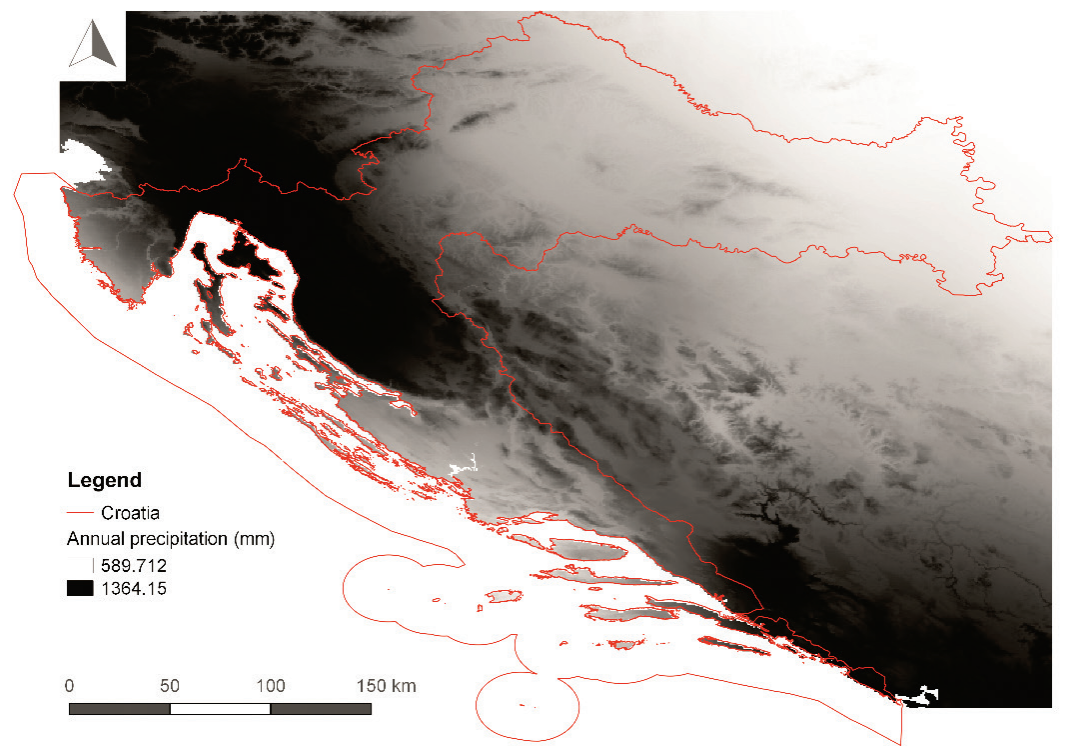

Slika 3. Prikaz izrezanog rasterskog sloja za klimatsku varijablu srednje godišnje količine oborina (Bio12) za područje Hrvatske

Figure 3 Clip of raster layer for climate variable of mean annual rainfall (Bio12) for Croatia

Testiranje modela napravljeno je na temelju 10 ponavljanja metodom Bootstrap jer je u analizi korišteno 395 GPS točaka nalaza vrste. Udio točaka za testiranje modela je $25 \%$. 
I. Ljubičić i sur.: Utjecaj ekoloških čimbenika na rasprostranjenje kranjskog ljiljana (Lilium carniolicum Bernh. ex Koch) u Hrvatskoj

Tablica 1. Korištene klimatske varijable u modeliranju ekološke niše Table 1 Climate variables used in ecological niche modeling

\begin{tabular}{|l|c|}
\hline $\begin{array}{c}\text { Naziv varijable } \\
\text { Name of variable }\end{array}$ & $\begin{array}{c}\text { Opis varijable } \\
\text { Decsription of variable }\end{array}$ \\
\hline Bio1 & Srednja godišnja temperatura \\
\hline Bio4 & Sezonska temperatura (standardna devijacija *100) \\
\hline Bio5 & Maksimalna temperatura najtoplijeg mjeseca \\
\hline Bio6 & Minimalna temperatura najhladnijeg mjeseca \\
\hline Bio7 & Srednja godišnja temperatura (bio5 - bio6) \\
\hline Bio9 & Srednja temperatura kvartala s najmanje padalina (najsuše) \\
\hline Bio10 & Srednja temperatura najtoplijeg kvartala \\
\hline Bio11 & Semperatura najhladnijeg kvartala \\
\hline Bio12 & Godišnje oborine \\
\hline Bio15 & Oborine najtoplijeg kvartala \\
\hline Bio18 & Oborine najhladnijeg kvartala \\
\hline Bio19 &
\end{tabular}

\section{REZULTATI I RASPRAVA}

Prikaz prediktivnog modela s obzirom na pogodnost staništa vrste Kranjski ljiljan (Lilium carniolicum Bernh. ex Koch) na području Republike Hrvatske u rezoluciji 1x1 km, prikazan je na Slici 4

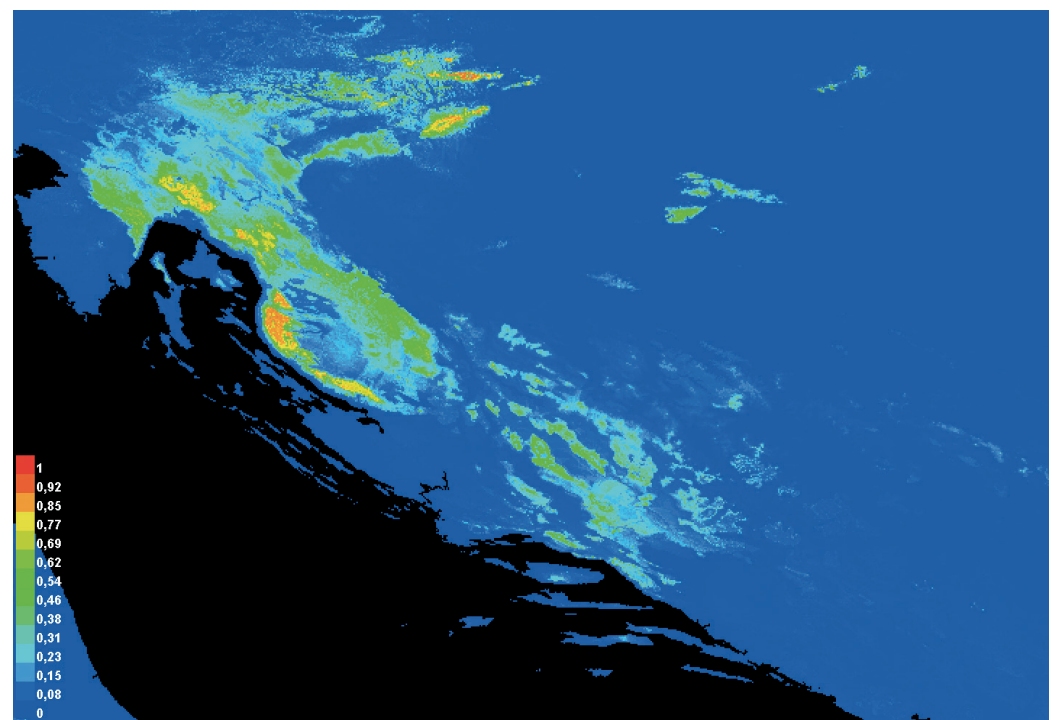

Slika 4. Pogodnost staništa Kranjskog ljiljana na području Republike Hrvatske.

Figure 4 Habitat suitability of the Carniolan lily in Croatia 
I. Ljubičić i sur.: Utjecaj ekoloških čimbenika na rasprostranjenje kranjskog ljiljana (Lilium carniolicum Bernh. ex Koch) u Hrvatskoj

Raspon vrijednosti piksela kreće se od 0 do 1 tj. od hladnije (plave) prema toplijoj (crvenoj) boji. Što je vrijednost piksela bliže 1 znači da je stanište povoljnije, a vrijednost piksela bliže nuli znači da je stanište nepovoljnije za kranjski ljiljan. Hladne boje prikazuju da je stanište nepovoljno, a zelena, žuta, narančasta i crvena boja da je stanište povoljno tj. da je vjerojatnost veća za obitavanje vrste (Elith i sur. 2011.).

Udio utjecaja klimatskih varijabli prikazan je u Tablici 2. Izdvojene i boldane su dvije klimatske varijable koje su imale statistički najveći utjecaj na formiranje prediktivnog modela.

Tablica 2. Bioklimatske varijable korištene za prediktivni model rasprostranjenosti vrste Lilium carniolicum (boldane vrijednosti su najviše utjecale na formiranje prediktivnog modela).

Table 2 Bioclimatic variables used for the predictive distribution model of Lilium carniolicum (bold values most by influencing the formation of the predictive model)

\begin{tabular}{|l|c|}
\hline $\begin{array}{c}\text { Bioklimatska varijabla } \\
\text { Bioclimatic variable }\end{array}$ & $\begin{array}{c}\text { Udio (\%) } \\
\text { Part (\%) }\end{array}$ \\
\hline Bio18* & $\mathbf{3 2 , 2}$ \\
\hline Bio5 $^{*}$ & $\mathbf{1 4 , 3}$ \\
\hline Bio12 & 13 \\
\hline Bio7 & 12,3 \\
\hline Bio11 & 7,1 \\
\hline Bio19 & 6,1 \\
\hline Bio15 & 6 \\
\hline Bio4 & 5,8 \\
\hline Bio6 & 1,3 \\
\hline Bio9 & 1 \\
\hline Bio1 & 0,6 \\
\hline Bio10 & 0,3 \\
\hline
\end{tabular}

$\mathrm{Na}$ formiranje modela ekološke niše Kranjskog ljiljana najviše je utjecala varijabla Bio18 koja označava oborine najtoplijeg kvartala. Slijedi varijabla maksimalne temperature najtoplijeg mjeseca Bio5 (14,3\%), varijabla Bio12 godišnje oborine (13\%) i Bio7 koja označuje srednju godišnju temperaturu (12,3\%). Varijable Bio6 (minimalna temperatura najhladnijeg mjeseca), Bio9 (srednja temperatura kvartala s najmanje padalina), Biol (srednja godišnja temperatura) i Bio10 (srednja temperatura najtoplijeg kvartala) imale su vrlo mali utjecaj na formiranje modela ekološke niše.

Grafički prikazi o točnosti modela ekološke niše prikazani su na Slikama 5 i 6. 
I. Ljubičić i sur.: Utjecaj ekoloških čimbenika na rasprostranjenje kranjskog ljiljana (Lilium carniolicum Bernh. ex Koch) u Hrvatskoj

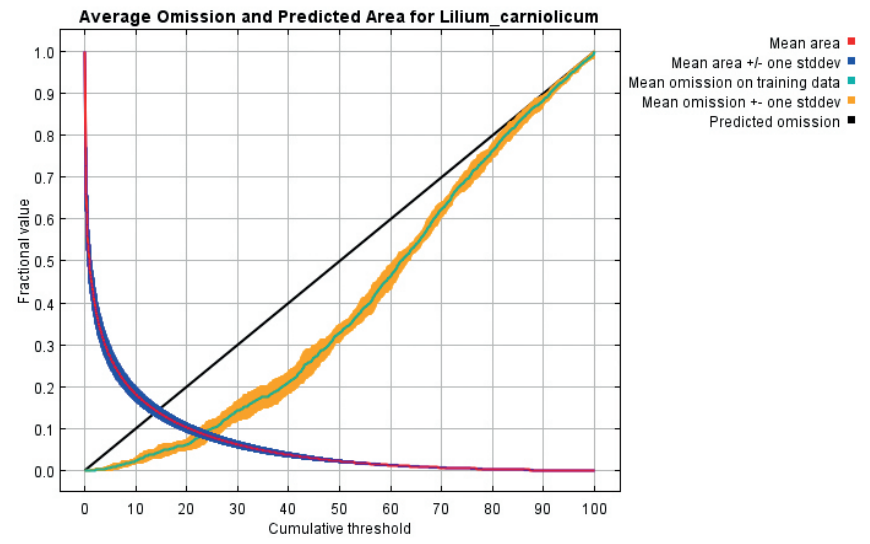

Slika 5. Grafički prikaz točnosti modela ekološke niše (narančasta i plava sjena oko linije predstavlja varijabilnost)

Figure 5 Graph displays the omission rate of predicted area (the orange and blue shading surrounding the lines on the graph represent variability)

$\mathrm{Na}$ Slici 5. je grafikon koji prikazuje odstupanje (omisiju) od predikcije (modela) i njihove standardne devijacije (odstupanje varijanata od srednje vrijednosti). Iz grafa uočavamo da prosječna omisija (zelena linija) ne odstupa značajno od predikcije modela (crna linija). Također i standardna devijacija nije značajna za prosječnu omisiju (žuta površina). Graf ukazuje na visok stupanj točnosti modela.

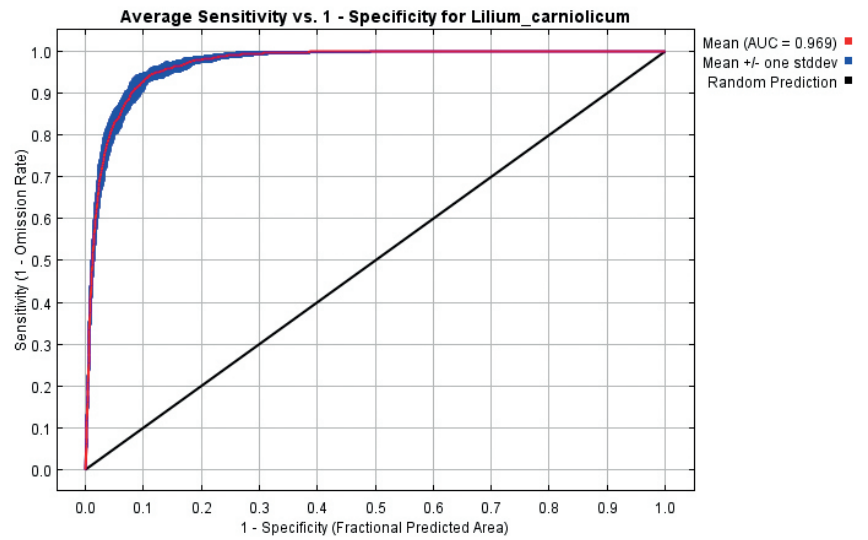

Slika 6. Grafički prikaz točnosti modela

Figure 6 The graph shows the Sensitivity vs 1 -Specificity 
I. Ljubičić i sur.: Utjecaj ekoloških čimbenika na rasprostranjenje kranjskog ljiljana (Lilium carniolicum Bernh. ex Koch) u Hrvatskoj

$\mathrm{Na}$ x osi prikazane su vrijednosti od 0-1 koje označavaju 1 - Specificity (udio točno zabilježenih točaka da nisu prisutne na geografskom prostoru), a na y osi se nalaze vrijednosti od $0-1$ za Sensitivity ( 1 - Omission Rate). Sensitivity je udio točno zabilježenih točaka o prisutnosti vrste, a Omission je udio krivo zabilježenih točaka da ne postoje. Što je omisija manja greška je manja u modelu. Vidljivo je da je Sensitivity jako blizu 1 od samog početka što nam ukazuje na visok stupanj točnosti modela.

Dobiveni model ekološke niše za Kranjski ljiljan prikazan je bojom (hladnije prema toplijima), a ukazuje na pogodnost staništa. Stanište gorske i planinske Hrvatske okarakterizirano je visokom ekološkom prikladnosti.

Usporedbom ovog $\mathrm{s}$ istraživanjima lanilista (Fernández-Mazuecos i Vargas, 2013), gdje je također korištena metoda maksimalne entropije, a od 19 klimatskih varijabli, korišteno ih je sedam koje nisu u međusobnoj korelaciji. S obzirom na to da je lanilist acidofilna vrsta, ovdje je izvedena i kategorijska varijabla koja razlikuje kisele i bazične supstrate. Pokazalo se da su dvije varijable temperature (Bio6 - minimalna temperatura najhladnijeg mjeseca $\mathrm{i}$ Bio5 - maksimalna temperatura najtoplijeg mjeseca) i jedna oborina (Bio14 oborine mjeseca s najmanje padalina) najviše utjecale na modeliranje ekološke niše. Može se utvrditi da varijable temperature u oba slučaja zauzimaju visok utjecaj na formiranje modela potencijalne distribucije vrste.

\section{ZAKLJUČAK}

Lilium carniolicum Bernh. ex Koch je ugrožena vrsta koja raste na livadama i šumskim rubovima brdskih i planinskih predjela. Koristi se u dekorativne svrhe te ima jestivu lukovicu.

S obzirom na velik potencijal ove vrste ljiljana, napravljen model ekološke niše pomoću metode maksimalne entropije pokazao se vrlo učinkovitim. Klimatska varijabla Bio18 pokazala se kao najutjecajnija na formiranje modela i rasprostranjenost kranjskog ljiljana s 32,2\%. Rezultati se podudaraju $\mathrm{s}$ njegovom utvrđenom rasprostranjenošću, a i ranija istraživanja rasprostranjenosti drugih vrsta pokazala su točnost programa. S obzirom na trenutne klimatske promjene, a i točnost metode u Maxent programu, metoda maksimalne entropije otvara mogućnosti za istraživanje ostalih potencijalnih vrsta. 
I. Ljubičić i sur.: Utjecaj ekoloških čimbenika na rasprostranjenje kranjskog ljiljana (Lilium carniolicum Bernh. ex Koch) u Hrvatskoj

\section{LITERATURA}

1. Anić I., Vukelić J., Mikac S., Bakšić D., Ugarković D. (2009.): Utjecaj globalnih klimatskih promjena na ekološku nišu obične jele (Abies alba Mill.). Šumarski list 3-4: 135-144.

2. Elith J., Graham C.H., Anderson R.P., Dudik M., Ferrier S., Guisan A., Hijmans R.J., Huettmann F., Leathwick J.R., Lehmann A., Li J., Lohmann L.G., Loiselle B.A., Manion G., Moritz C., Nakamura M., Nakazawa Y., Overton J.M., Peterson A.T., Phillips S.J., Richardson K., Scachetti-Pereira R., Schapire R.E., Sobero'n J., Williams S., Wisz M.S., Zimmermann N.E. (2006.): Novel methods improve prediction of species' distributions from occurrence data. Ecography 29: 129-151.

3. Elith J., Phillips S.J., Hastie T., Dudik M., Chee Y.E., Yates C. (2011.): A statistical explanation of MaxEnt for ecologists. Diversity and Distributions 17: 43-57.

4. Fernández-Mazuecos M., Vargas P. (2013.): Congruence between distribution modelling and phylogeographical analyses reveals Quaternary survival of a toadflax species (Linaria elegans) in oceanic climate areas of a mountain ring range. New Phytologist 198(4): 1274-1289.

5. Fick S.E., Hijmans R.J., (2018.): Worldclim 2: New 1-km spatial resolution climate surfaces for global land areas. International Journal of Climatology.

6. Hirzel A.H., Hausser J., Chessel D., Perrin N. (2002.): Ecological-niche factor analysis: how to compute habitat-suitability maps without absence data? Ecology 83 2027-2036.

7. Kumar S., Stohlgren T.J. (2009.): Maxent modeling for predicting suitable habitat for threatened and endangered tree Canacomyrica monticola in New Caledonia. Journal of Ecology and Natural Environment 1(4): 94-98.

8. Ljubičić I., Britvec M., Plazibat M., Vitasović Kosić I. (2010.): Flora of the South-Western Part of the National Park "Northern Velebit". Poljoprivredna znanstvena smotra 75(2): 67-73.

9. Mihelj D. (1989.): Kranjski ljiljan. Priroda: časopis za popularizaciju prirodnih znanosti i ekologije (Hrvatskoga prirodoslovnog društva) 78-79(1): 16-17.

10. Nikolić T. ur. (2020.): Flora Croatica baza podataka. Botanički zavod, Prirodoslovno-matematički fakultet, Sveučilište u Zagrebu.

11. Nikolić T., Topić J. ur. (2005.): Crvena knjiga vaskularne flore Republike Hrvatske. Kategorije EX, RE, CR, EN i VU. Ministarstvo kulture, Državni zavod za zaštitu prirode, Zagreb. 
I. Ljubičić i sur.: Utjecaj ekoloških čimbenika na rasprostranjenje kranjskog ljiljana (Lilium carniolicum Bernh. ex Koch) u Hrvatskoj

12. Oke O.A., Thompson K.A. (2015.): Distribution models for mountain plant species: The value of elevation. Ecological Modelling 301: 72-77.

13. Pearson R.G., Raxworthy C.J., Nakamura M., Peterson A.T. (2007.): Predicting species distributions from small numbers of occurrence records: a test case using cryptic geckos in Madagascar. Journal of Biogeography 34: 102-117.

14. Phillips S.J., Anderson R.P., Schapire R.E. (2006.): Maximum entropy modeling of species geographic distributions. Ecological Modelling 190: 231-259.

15. Phillips S.J., Dudig M. (2008.): Modeling of epecies distributions with Maxent: new extensions and a comprehensive evaluation. Ecography 31: 161-175.

16. Rešetnik I., Baričevič D., Batîr Rusu D., Carović-Stanko K., Chatzopoulou P., Dajić-Stevanović Z., et al. (2016.): Genetic Diversity and Demographic History of Wild and Cultivated/Naturalised Plant Populations: Evidence from Dalmatian Sage (Salvia officinalis L., Lamiaceae). Plos One 11(7): 1-23.

17. Trinajstić I. (2008.): Biljne zajednice Republike Hrvatske. Akademija šumarskih znanosti, Zagreb.

18. Vessella F., Schirone B. (2013.): Predicting potential distribution of Quercus suber in Italy based on ecological niche models: Conservation insights and reforestation involvements. Forest Ecology and Management 304: 150-161.

19. Vitasović Kosić I., Britvec M., Ljubičić I., Maštrović Pavičić D. (2009.): Vaskularna flora Istre: ugrožene i rijetke vrste. Agronomski Glasnik 71(3): 199-213.

20. Yi Y., Cheng X., Yang Z.F., Zhang S.H. (2016.): Maxent modeling for predicting the potential distribution of endangered medicinal plant $(H$. riparia Lour) in Yunnan, China. Ecological Engineering 92: 260-269.

Adresa autora - Author's addresses:

Ivica Ljubičić, e-mail: iljubicic@agr.hr, Marija Horvat,

Tamara Brlek,

Sveučilište u Zagrebu, Agronomski fakultet

Svetošimunska cesta 25, 10000 Zagreb
Primljeno - Recived:

20.01.2020. 